\title{
Book Review: The American Indian Oral History Manual: Making Many Voices Heard
}

Hiram F. Gregory

Unknown

Follow this and additional works at: https://scholarworks.sfasu.edu/ita

Part of the American Material Culture Commons, Archaeological Anthropology Commons, Environmental Studies Commons, Other American Studies Commons, Other Arts and Humanities Commons, Other History of Art, Architecture, and Archaeology Commons, and the United States History Commons

Tell us how this article helped you.

This Article is brought to you for free and open access by the Center for Regional Heritage Research at SFA ScholarWorks. It has been accepted for inclusion in Index of Texas Archaeology: Open Access Gray Literature from the Lone Star State by an authorized editor of SFA ScholarWorks. For more information, please contact cdsscholarworks@sfasu.edu. 
Book Review: The American Indian Oral History Manual: Making Many Voices

Heard

Creative Commons License

(c) (1) (9)

This work is licensed under a Creative Commons Attribution-NonCommercial 4.0 International License 


\section{BOOK REVIEW}

\section{The American Indian Oral History Manual: Making Many Voices Heard. \\ Charles E.Trimble, Barbara W. Sommer and Mary Kay Quinlan \\ Left Coast Press, Walnut Creek, California, 2009}

\section{Reviewed by Pete Gregory}

The times have changed. American Indian people, like indigenous population worldwide, have finally begun to impress scholars with the fact that in spite of centuries of colonial exploitation their cultures are alive and they hold ownership of them. Oral history and ethnology both have to listen to this new voice and come to understand the ethical and legal implications for the academic disciplines. These three authors bring unique experiences as well as "best practice training" to this small book.

The work is designed for use by American Indians and as such becomes a guide to non-Indian scholarship as well. The authors understand the need for oral history in American Indian communities and they also know that oral tradition is the source of tribal knowledge. Charles Trimble has discussed the problem of collection and maintaining traditions. His eloquent introduction takes the fieldworker to the heart of his personal experience, but it is a lament heard over and over in Indian Country,

"However, I often cringe when I think of what I missed in not recording on paper some of the experiences and wisdom of those tribal elders, which I was privileged to hear in my youth."

With these things said, this neat little manual lays out ethics and legal issues, with a more than adequate set of endnotes that carries the American Indian issues neatly into the world of indigenous people. These issues explain tribal and Federal law, and give references that help the fieldworker understand the dos and don'ts that separate these indigenous issues from other ethical and legal matters.

The other sections deal with best practice, most of the time as it is recommended by the guidelines set forth by the Oral History Association. This includes discussions of permission forms, access to the materials collected, archival concerns, and again, tribal and individual rights and privacy issues. These are important for any oral history practitioner and are made relevant here for American Indian historians.

The sections on everything from project planning and funding to equipment and suggestions for sampling and interviewing are all covered thoroughly, yet efficiently. The field forms are well designed, equipment is competently discussed in lay terms, and finally, there is an excellent bibliography that supplements the really fine endnotes that follow each section.

This work should be in the hands of every Tribal Historic Preservation Office. It answers lots of questions and raises others that need raising. It is a constructive tool in the preservation of American Indian culture and one that comes to that task with those "experiences and wisdom" that Trimble noted having heard personally.

This is a book for the American Indian people-it has knowledge and heart. 